\title{
A Model for the Regionalization of Higher Education: The Role and Contribution of Tuning ${ }^{1}$
}

\author{
Jane Knight
}

\begin{abstract}
A notable evolution in the internationalization of higher education in the last decade has been the increasing emphasis on regional level collaboration and reform initiatives. The purpose of this paper is to examine the process of regionalization through the lens of a conceptual model and to demonstrate how different Tuning initiatives serve as useful instruments in the application of the model, and the ultimate realization of higher education regionalization. The evolving nature and meaning of region and regionalization are explored in the first section of the paper. This leads to an analysis and conceptual mapping of the many terms used to describe the phenomenon. The proposed model is based on three distinct but complementary approaches; Functional, Organizational and Political Approaches (FOPA). The three approaches are inter-related. The model is generic in concept and purpose so that it can apply to the evolving process of higher education regionalization in different parts of the world. The article examines how the initiatives and implications of the Tuning process are directly related to the model and consequently make important contributions to the regionalization of higher education in all regions of the world.
\end{abstract}

Keywords: Regionalization; system alignment; curriculum convergence; credit systems; qualification frameworks; organizational; functional; political; African Union; Latin America; Bologna; Europe; Central Asia.

\section{Introduction: Importance and expansion of higher education regionalization}

A notable evolution in the internationalization of higher education in the last decade has been the increasing emphasis on regional level collaboration and reform initiatives. ${ }^{2}$ The growing number of regional based university

${ }^{1}$ Parts of this paper are based on: Knight, "A Conceptual Framework for the Regionalization of Higher Education: Application to Asia," and Knight, "Towards African Higher Education Regionalization and Harmonization: Functional, Organizational and Political Approaches," in The Development of Higher Education in Africa: Prospects and Challenges, edited by Alexander W. Wiseman and C. Wolhuter. International Perspectives on Education and Society Series (UK: Emerald Publishing, 2013).

2 Jane Knight, Higher Education in Turmoil: The Changing World of Internationalization, Global Perspectives on Higher Education, V. 13 (Rotterdam: Sense Publishers, 2008). 
networks, regional student mobility programs, and pan-regional higher education associations are only a few examples. More significant is the development of regional level frameworks for academic credit systems, quality assurance, and qualifications frameworks as these reforms are based on a closer alignment of systems and policies. The Bologna Process in Europe is the most significant illustration of this regional level of reform. Supporters and critics of the Bologna process, both internal and external to Europe, agree that it continues to be the boldest and largest planned effort to enhance regionalization of higher education in the world. ${ }^{3}$ Opinions differ on the driving rationales, long-term outcomes, unintended consequences, and next steps of the Bologna process. But, there is no question that it has propelled other regions and sub-regions around the world to look more seriously at the significance and modality of building closer alignment of their higher education systems.

A review of recent initiatives in Africa, Asia and Latin America demonstrate the importance attributed to higher education realization. For example, in 2007 the African Union released a major report "Harmonization of Higher Education Programmes in Africa: A Strategy for the African Union" which focused on building closer links among higher education institutions, networks, national systems, regional university associations and other key higher education actors. ${ }^{4}$ An interesting feature of creating a panAfrican higher education and research space is the emphasis on strengthening the capacity and role of regional university associations. ${ }^{5}$ Examples of current African higher education regionalization initiatives include the African Quality Rating Mechanism, the Nyerere African Scholarship scheme, AfriQAN- network of quality assurance agencies, regional centres of excellence, updated Regional UNESCO Arusha Convention on the Recognition of Qualifications, a Pan-African University, and the new Open Education Africa project. Regional level initiatives to facilitate the establishment and alignment of quality assurance and accreditation systems, student mobility schemes, common degree levels, a research/education ICT backbone, and research networks are in now in progress. These initiatives

${ }^{3}$ Christian Tauch, "The Bologna Process: State of Implementation and External Dimension," in Opening up to the Wider World: The External Dimension of the Bologna Process, edited by F. Muche. ACA Papers on International Cooperation in Education, 23-29 (Bonn: Lemmens, 2005).

4 African Union, "Harmonization of Higher Education Programmes in Africa: A Strategy for the African Union: Summary Report," Addis Ababa: Meeting of the Bureau of the Conference of Ministers of Education of the African Union (COMEDAF II+), African Union, 2007.

5 Yohannes Woldetensai, Regional Harmonization of Higher Education for Africa: Background Document (Accra: Association of African Universities, 2009). 
illustrate the intention and commitment of Africa to establish stronger pan regional collaboration and harmonization of systems while still recognizing the importance of bilateral and multi-lateral internationalization efforts. ${ }^{6}$

The higher education regionalization scenario in Asia is complex and evolving. To date, most efforts towards enhancing higher education regionalization have been within South East Asia, but not exclusively. For instance, the Asia Pacific Quality Assurance Network was established in 2004 and covers 53 countries in Asia. Among its goals is capacity building within nations to establish national quality assurance systems and greater mutual recognition and collaboration among member countries. The University Mobility in Asia Pacific program (UMAP) is a student mobility project which was established over fifteen years ago. The Association of South East Asia Nations (ASEAN) decided in 2003 to embark on a program of strengthening relations and activities among higher education institutions through the establishment of the ASEAN University Network (AUN) which is comprised of 26 leading universities in South East Asia. The AUN in turn has developed a series of thematic networks and projects which primarily involve member institutions but is yielding to pressure to include other universities in their regional conferences and projects.

Another key player in Asia higher education scene is the South East Ministers of Education Organization (SEAMEO). It has established a series of 22 centres throughout the region which deal with specific aspects of education. The Regional Centre for Higher Education Development (RIHED) has undertaken an impressive number and diversity of projects to create a stronger frame of collaboration among the 11 member countries of South East Asia. Examples of initiatives undertaken include the ASEAN Quality Assurance Network, the ASEAN regional research citation index, the ASEAN regional credit transfer system, and the ASEAN Higher Education Clusters. ${ }^{7}$ Many of these schemes are in early stages of development and will take time to mature and be sustainable. Interestingly countries outside of South East Asia are starting to be included in these projects. For instance Japan has recently joined the MIT (Malaysia, Indonesia, Thailand) Student Mobility Scheme organized by RIHED. ${ }^{8}$

\footnotetext{
${ }^{6}$ Sarah Hoosen et al., "Harmonization of Higher Education Programmes: A Strategy for the African Union," African Integration Review 3, no. 1 (2009): 1-36.

${ }^{7}$ R Aphijanyathan, "A Research Report on East Asian Internationalization of Higher Education: A Key to Regional Integration,” Program Report 24, Bangkok: Regional Centre for Higher Education and Development, South East Ministers of Education Organization, 2010.

${ }^{8}$ Supachai Yavaprabhas, "Experiences of Asian Higher Education Frameworks and Their Implication for the Future," GIARI Working Paper 2008-E.19, Tokyo: Waseda University, 2009.
} 
Campus Asia, a program created in 2010, is the most recent project to build closer ties among Korea, Japan and China through student mobility and quality assurance. Campus Asia is a result of the second Tri-lateral East Asia Summit held in 2009. This mobility scheme is still working out the complexities of quality assurance mechanisms, credit systems, and the controversial but central issue of language. Although it is currently focused on mobility for students in Korea, China and Japan, it hopes to expand and include students from other East Asian nations.

In Latin America and the Caribbean (LAC) a major new initiative for the regionalization of higher education has been established as result of a region wide UNESCO conference held in 2008. The name of the initiative is ENLACES which, in English, means the Latin America and the Caribbean Area for Higher Education. This project is hosted by IESALC- the UNESCO Institute for Higher Education in Latin America and the Caribbean. ENLACES is a regional platform formally created for the mobilization of projects and studies that support academic cooperation and knowledge sharing in the region. Membership in this initiative is open to individuals, institutions, government bodies, organizations and networks in all LAC countries. The ultimate goal is to promote improved quality and relevance of higher education so that it can better serve society.

A major activity is the development of a Map of Higher Education in LAC. This project brings together data on national higher education systems in order to facilitate academic mobility and the development/alignment of national and institutional policies. For example, there is a strong commitment to facilitate the convergence of national and sub-regional assessment and accreditation systems with the involvement of the IberoAmerican Network for the Accreditation and Quality of Higher Education (RIACES). Two other priorities are the mutual recognition of studies, titles, and diplomas based on quality assurance, as well as the establishment of common academic credit systems accepted throughout the region. Fostering the intra-regional mobility of students, researchers, faculty, and administrative staff through the implementation of funded programs is another area of activity. The establishment of multi-university and multi-disciplinary teaching and research networks is part of the work plan, as is developing shared distance education programmes within the region. Finally, strengthening the learning of languages present in the region to foster the kind of regional integration that incorporates cultural diversity and multilingualism is a primary concern and modality for building the common higher education area in LAC.

These brief descriptions illustrate the diversity of actors and projects which are contributing to the regionalization of higher education in three regions of the world. Some activities are well established programs while 
others have only been introduced in the last few years. At the same time, inter-regional cooperation is expanding as well. In fact, Europe is investing considerable efforts and funds into promoting the Bologna reforms to other parts of the world through establishing inter-regional mobility programs, policy dialogues, and institutional network projects. Interestingly, a number of these efforts are in fact bilateral initiatives i.e., between Europe as a region to a single country or sub-region. This is due to the fact that regional level higher education agencies or frameworks do not exist in other regions as they do in Europe. There is no doubt that Europe is a catalyst and model for regionalization initiatives. Other regions are benefiting from the Bologna Process, but they are giving careful consideration on how to adapt the European experiences to their own stage of development, their own cultural, historical and political contexts, and most importantly their own reasons for promoting regionalization. There is awareness of the subtle but evident soft power agenda of Europe's significant investment in promoting Bologna reforms and closer inter-regional cooperation.

\section{Tuning project and process}

The Tuning Project is an interesting and successful initiative which has addressed the reform of institutional level structures through curriculum convergence but which has important implications for the regionalization of higher education at sub-regional and regional levels.

In 2000, the first Tuning Project was launched in Europe at the same time that the Bologna process of higher educational reform was underway. The focus of the project was the 'elaboration of a framework of comparable and compatible qualifications' in each of the (potential) signatory countries of the Bologna process. The aim was to develop a common understanding of qualifications described in terms of workload, level, learning outcomes, competences and profile. In turn this could lead to the eventual creation of a European wide Qualifications Framework. ${ }^{9}$ In the 13 years since its launch, Tuning has expanded from its original European focus to other regions and countries of the world and more importantly, it has evolved into a respected 'process' of reforming education structures at the institutional level by developing common reference points for subjects, program profiles and now meta profiles.

9 Julia González, and Robert Wagenaar, "Universities' Contribution to the Bologna Process. An Introduction," University of Deusto, 2008, http://www.unideusto.org/tuningeu/ images/stories/Publications/ENGLISH_BROCHURE_FOR_WEBSITE.pdf. 19 January 2013. 
Because the Tuning approach has worked on common understandings and reference points leading to comparable and compatible qualifications within and among countries, it has significant implications for the regionalization agenda of higher education. The work of Tuning in Latin America is a good example of this. As a result of two major Tuning Projects in Latin America, from 2004-2007 and 2011 to 2013, progress has been made toward achieving a significant level of convergence across Latin American in fifteen subject areas, a workload based credit system for use across the region, and a regional network of national Tuning Centres to facilitate learning outcome based teaching, learning, and evaluation strategies. ${ }^{10}$ Furthermore, according to the Central American Council of Universities (CSUCA) which has been active in these projects, the work of Tuning has contributed to the process of academic harmonization for the improvement and integration of a regional higher education system in Central America. ${ }^{11}$

In 2012, a Tuning Africa initiative was launched with the express purpose of contributing to the realization of the African Union Strategy for Harmonization of Higher Education Programmes (AU-HEP)..$^{12}$ The AU-HEP aims to increase cooperation in information exchange, harmonization of procedures and policies, and attainment of comparability among qualifications to facilitate professional mobility for both employment and further study. The work of the African Tuning initiative is intended to contribute to the African Union Harmonization strategy and help to foster mobility of students in Africa through a qualifications recognition scheme and a regional academic credit system; enhance the quality of education and employability through a learning outcome based approach to curriculum development, and contribute to the harmonization of education structures and systems across the continent. ${ }^{13}$ Similarly in Central Asia, a new Tuning project is designed to contribute to building a Central American Higher Education Area (CAHEA) through the development of competency based profiles for a range of subject areas which will eventually help to establish comparable qualification profiles as the basis for a Central AmericanQualifications

${ }^{10}$ Tuning Latin America Project (Tuning Latin America), "Objectives Tuning Latin America,” 2011, http://www .tuningal.org/en/tuning-project/objetives. 18 January 2013.

${ }^{11}$ Francisco Alarcon, "Vinculando Tuning a las Políticas Nacionales, Subregionales y Regionales: La Experiencia de América Central," Presentation of 4th Tuning Project Meeting in Brussels, Tuning America Latina, 2012, http://www.tuningal.org/es/publicaciones/cat_ view/44-presentaciones-reunion-bruselas-19-22-nov-2012. 19 January 2013.

12 African Union, "Harmonization of Higher Education Programmes in Africa."

${ }^{13}$ Beatrice Njenga, "Tuning Approach for Harmonisation of Higher Education in Africa," Presentation at 4th Tuning Project Meeting in Brussels, Tuning Latin America, 2012, http:// www.tuningal.org/es/publicaciones/cat_view/44-presentaciones-reunion-bruselas-19-22nov-2012. 19 January 2012. 
Framework and a credit system. ${ }^{14}$ These concrete examples demonstrate the growing importance of higher education regionalization in all continents and the contribution that the Tuning process can make to these regionalization efforts.

\section{Purpose and outline of paper}

The purpose of this paper is to examine the process of regionalization through the lens of a conceptual model and to demonstrate how different Tuning initiatives serve as useful instruments in the application of the model and the ultimate realization of higher education regionalization.

The outline of the article is as follows: The first section explores the meaning of regions and regionalization and identifies four lines of inquiry which in turn leads to an analysis of the myriad of terms used to describe regionalization. The key concepts are mapped on a continuum which is anchored by the notions of cooperation and collaboration at one end moving to more formalized and intentional concept of integration and interdependence at the other end. The next section introduces a conceptual model for the regionalization of higher education. The model is based on three distinct but complementary approaches; Functional, Organizational and Political Approaches (FOPA). The three approaches are inter-related; they are not independent silos of activities. The model is generic in concept and purpose so that it can apply to the evolving processes of higher education regionalization in different parts of the world. Examples of different types of initiatives are provided to elucidate the FOPA framework and illustrate the relationship among the three approaches. The final section looks at how the initiatives and implications of the Tuning process are related to the model and consequently make important contributions to the regionalization of higher education in its many diverse forms in all regions of the world.

The tripartite FOPA model is a work in progress. It needs to be generic enough to encompass different approaches but specific enough to be useful for empirical analysis and comparison. Higher education is the main focus, but the model has relevance to the broader tertiary education sector. The model concentrates on the process of facilitating closer collaboration and alignment among higher education institutions, actors, networks and systems within a designated area or framework. Furthermore, the model builds on the

${ }^{14}$ Robert Wagenaar, "Tuning Educational Structures around the World. An Overview of the Developments in Different Regions," Presentation at 4th Tuning Project Meeting in Brussels, Tuning Latin America, 2012, http://www.tuningal.org/es/publicaciones/cat_view/44presentaciones-reunion-bruselas-19-22-nov-2012. 19 January 2013. 
multitude of activities, reforms, and networks that are already functioning and improving higher education and its contribution to society.

\section{Understanding Regions and Regionalization}

A review of the terminology related to the concept of region is like opening Pandora's Box. As regions evolve and change so does the interpretation and use of key terms. The diversity of disciplines examining the topic of regionality brings a different lens to the discourse and vividly illustrates that the concept of region is both complex and elusive. A myriad of definitions and interpretations exist.

Traditionally region has been defined in geographic terms and primarily as a collection of nation states in a particular geographically designated area.$^{15}$ Due to the more interconnected and interdependent world in which we live, the idea of region is becoming more elastic and porous. In both theory and practice, regions can be overlapping, multi-layered, multi-actor, and multi-faceted and can be politically, socially, functionally, and culturally defined. ${ }^{16}$ Regions can be sub-national and supra-national. The supranational level is the focus of this paper but this level is also layered as it can include sub-regional, regional and pan- regional levels. Nation state is no longer always at the core of region, especially for culturally based regions. Regions do not need to be based on boundaries anymore; the connections and interactions among key actors are of greater import than the defining perimeter. The focus is on the dynamic processes of building a region. Thus, the model is intended to be applicable to higher education regionalization in any region; however it is delineated by the user. It could be in geographic terms such as major world regions Africa, Europe, ${ }^{17}$ Latin America, or smaller regions such as South East Asia,${ }^{18}$ Eastern Europe,${ }^{19}$ Sub-Saharan

${ }_{15}$ Raimo Vayrynen, "Regionalism: Old and New," International Studies Review 5, no. 1 (2003): 25-51.

${ }^{16}$ Björn Hettne, "Beyond the New Regionalism," New Political Economy 10, no. 4 (2005): 543-71.

17 Susan Robertson, "Europe/Asia Regionalism, Higher Education and the Productions of World Order," Policy Futures in Education 6, no. 6 (2008): 718-29.

${ }^{18}$ Kazuo Kuroda, and D. Passarelli, eds., Higher Education and Asian Regional Integration Symposium Report (Tokyo: Global Institute for Asian Regional Integration, Waseda University, 2009).

19 Adriana Gorga, "Where Are We with the Harmonization of European Higher Education? The Case of Central and East European Countries," European Education 39, no. 4 (2008): 58-68 
Africa, or cultural/linguistic terms such as Francophone Africa or Arab States, or in political/economic terms such as Asia Pacific Economic Community or Mercosur. ${ }^{20}$

A review of academic articles and grey literature reveals a vibrant debate on the topic of regions and their importance, formation and function. It is interesting to note the different interpretations and permutations of the concept of region. Frequently used terms include regionalism, regionalness, regionality, regionalization, regional integration, inter-regional cooperation... to name a few. An examination of how these terms relate to the higher education sector leads to four lines of inquiry: 1) the impact of regionalism on higher education; 2) higher education regionalization 3) higher education as an instrument for regional integration and 4) inter-regional cooperation in higher education.

The 'impact of regionalism on higher education' focuses on how the changing notion and increasing importance of region is affecting higher education. It can lead to a type of trend analysis study where higher education is seen in more of a reactive position to the increasingly significant influence of the ideology of regionalism. 'Higher education regionalization' introduces the process of intentionally building connections and relationships among higher education actors, structure and systems within a region. Regionalization attributes more of a proactive role and 'agency' to higher education. 'Higher education as a tool for regional integration' takes a more tactical approach to how higher education can be used to achieve regional integration. Given the importance of the knowledge economy, higher education is perceived as a tool for the overall goal of regional economic integration. Higher education can be seen as a means to an end and the end is often stated in political and/ or economic integration terms. Inter-regional cooperation in higher education introduces yet another direction of inquiry which involves interactions between two regions. It often means two world regions such as Asia and Europe, although it could also be regions of smaller scale. Interregional cooperation is clearly different from intra-regional cooperation, with the pivotal point being how region is defined.

All lines of inquiry merit further examination but this paper focuses on the second line of inquiry 'higher education regionalization'. For the purposes of this discussion regionalization of higher education is defined as the "process of building closer collaboration and alignment among higher education actors and systems within a defined area or framework called a

${ }^{20}$ R. Robledo, and A. Caillon, "Regional Processes in Higher Education. The University Course Accreditation Mechanisms in the Mercosur and Regional Recognition of Diplomas and the Quality of Training," Journal of Higher Education and Society 14, no. 1 (2009): 73-98. 
region". ${ }^{21}$ Three points are key to this definition. The first is the idea that it is an on-going and evolutionary process, the second is the notion of intentional region building based on existing and new relationships and activities by a diversity of actors, and third is the view that region is defined by the players involved and can be interpreted as an specific area or an organizational/ programmatic/ political framework.

\section{Conceptual mapping of regionalization terms}

The analysis of the 'process of higher education regionalization' involves a multitude of terms such as collaboration, harmonization and integration. At times, the terms are used interchangeably, and at other times they have very different meanings. While this confusion of terms is not unusual with new developments, it does lead to misunderstandings and muddles. The terms and concepts that are most commonly linked to regionalization include the following: cooperation, integration, harmonization, convergence, collaboration, community, coherence, partnership, and alignment. Worth noting is the number of words that start with 'co' indicating the notion of 'togetherness'. The similarity among these terms is striking but when studied more closely subtle and important differences emerge. The next section focuses on the conceptual mapping of these terms, their meaning, and their relation to one another.

It is both challenging and enlightening to discern the differences and similarities among these terms and then try to group and map them. This could be criticized as a rather subjective and normative exercise, but the purpose is to stimulate reflection and raise questions. The categorization of terms is highly influenced by the language of analysis. What these terms mean in English will probably differ from how they are used in Japanese, Spanish or Arabic. Thus, it is important to ask what is the principle factor for grouping the terms and secondly, what does movement along the continuum or scale represent. In short, the groups include terms of similar levels of intensity of activity and the continuum represents the degree of intended 'togetherness' or what is often labelled 'regionalness'.22

${ }_{21}$ Jane Knight, "A Conceptual Framework for the Regionalization of Higher Education: Application to Asia," in Higher Education Regionalization in Asia Pacific. Implications for Governance, Citizenship and University Transformation, edited by John N. Hawkins, Ka Ho Mok, and Deane E. Neubauer (London: Palgrave Macmillan, 2012).

${ }_{22}$ Takashi Terada, "Constructing an 'East Asian' Concept and Growing Regional Identity; from EAEC to ASEAN +3," The Pacific Review 16, no. 22 (2003): 51-277. 
The continuum is anchored by the concepts of cooperation at one end and integration at the other. Cooperation represents a fairly loose and open kind of relationship while integration denotes a much stronger cohesion and collective type of arrangement often referred to as a community or 'common area'. The risk of placing these terms on a continuum is that regionalization is understood to be a linear progression along this scale. This is definitely not the case as change rarely happens in such a systematic way. Most importantly, the objectives and anticipated outcomes of regionalization differ among regions and for various regionalization strategies. One region may be working towards alignment and collaboration rather than harmonization and convergence while other regions may make integration the ultimate goal. An effective way to look at this continuum is through a musical metaphor. The collaboration and partnership group can be likened to an informal jazz concert where musicians gather to play the same composition with individual interpretations while the harmonization and integration end can be compared to a professional orchestral performance where different musicians are playing the same musical composition under a single conductor and common interpretation of the music. ${ }^{23}$

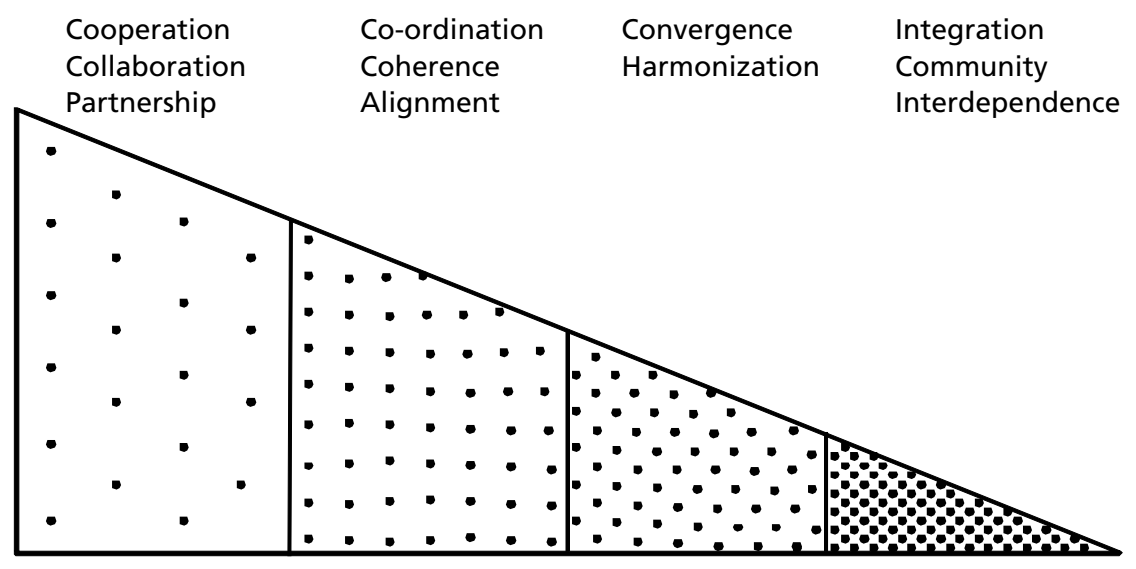

Figure 1

Mapping of Higher Education Regionalization Terms ${ }^{24}$.

23 Supachai Yavaprabhas, "Regional Harmonization of Higher Education in Asean," a paper presented at the 2010 Global Higher Education Forum, Penang, 2010.

${ }^{24}$ Knight, "A Conceptual Framework for the Regionalization of Higher Education: Application to Asia”. 
Figure one presents a schematic diagram of the conceptual mapping. The first group includes cooperation, collaboration and partnership. Networking could be added to this list. These terms denote an open, voluntary and perhaps informal type of relationship among actors. In practical terms, it describes the multitude of bilateral and multilateral collaborative activities by universities and other higher education actors.

The second group of terms- coordination, coherence and alignmentintroduces an element of organization and most likely some adaptation to ensure that the interactions among higher education actors in the region are complementary, productive and bring added value. In practice, this would include the organized networks, joint education programs, or research partnerships among higher education institutions, structures and systems.

The third group of terms- harmonization and convergence- involves stronger and more strategic links and can involve systemic changes both at institutional and national levels. This can include the development of regional quality assurance schemes; an academic credit system with a common currency for determination of credit based on workload; a qualifications framework, regional citation index; or compatible academic calendars.

The fourth group of terms- integration and community or common area- represents more formalized, institutionalized and comprehensive levels of connection and relationships. In practice this would involve regional level agreements and bodies that aim to facilitate a more robust and sustainable type of regional work and influence such as 'a common higher education and research space.' It is important to emphasize that this is a mapping of concepts not a depiction of the phases of the regionalization process.

It is equally interesting to look at concepts which are intentionally not included in this conceptual mapping but which are used and appear in the literature. Terms such as standardization, conformity, uniformity, compliance, and homogenization are omitted because they do not acknowledge the important differences among systems and actors within a region. This underlines a fundamental value or tenet of higher education regionalization which is respect for and recognition of differences and diversity among key actors, systems, and stakeholders. Failure to recognize this diversity can lead to the "zipper effect" whereby being completely interlocked can neglect differences, stifle innovation, and lead to homogenization.

A review of the Tuning documents and reports reveals that it uses many of the same terms when trying to describe both the goals of the project and the Tuning process. Terms which are central to Tuning and most commonly 
used include reference points, convergence and common understanding. According to the founders of the Tuning Project, convergence as defined in the Tuning project involves "the voluntary recognition and adoption of general policies for the achievement of common goals." ${ }^{25}$ Key concepts in this definition are voluntary recognition and adoption of general policies which interestingly relate closely to the third group on the continuum. The Tuning leaders carefully state that "the name Tuning is chosen for the Process to reflect the idea that universities do not and should not look for uniformity in their degree programmes or any sort of unified, prescriptive or definitive ... curricula but simply look for points of references, convergence and common understanding". ${ }^{26}$ This is clearly and emphatically enunciated to address criticisms that Tuning is a standardizing exercise and contributes to the aforementioned zipper effect which ignores differences and individual contexts. Common understandings and references points recognize and respect both differences and commonalities. Convergence represents a rather stringent level of "togetherness" but is softened by the notion of voluntary. However, when national and regional policies are developed, voluntary adoption is often not the preferred option.

Regionalization can be understood as an intentional process, a desire to build on what is already happening within the region and move beyond an ad hoc situation of cooperation to a more planned approach. Tuning is a process which appears to both stimulate and build on collaborations in a strategic and hopefully sustainable way.

\section{The Functional, Organizational and Political Approaches (FOPA) Model}

Three inter-related approaches- the functional approach, the organizational approach and the political approach - constitute the core of the proposed model. These approaches are not mutually exclusive. They are not three separate silos; they work in unison complementing and reinforcing each other. While this is the optimal situation it does not always happen in practice because conflicting priorities or politics can cause tension among the three approaches. At any one time, one approach could be more dominant than another; but, ultimately there needs to be progress on all three to ensure sustainability. Figure Two illustrates the relationship and intersection of these three approaches.

${ }^{25}$ González and Wagenaar, "Universities' Contribution to the Bologna Process," 148.

${ }^{26}$ Ibid., 5 


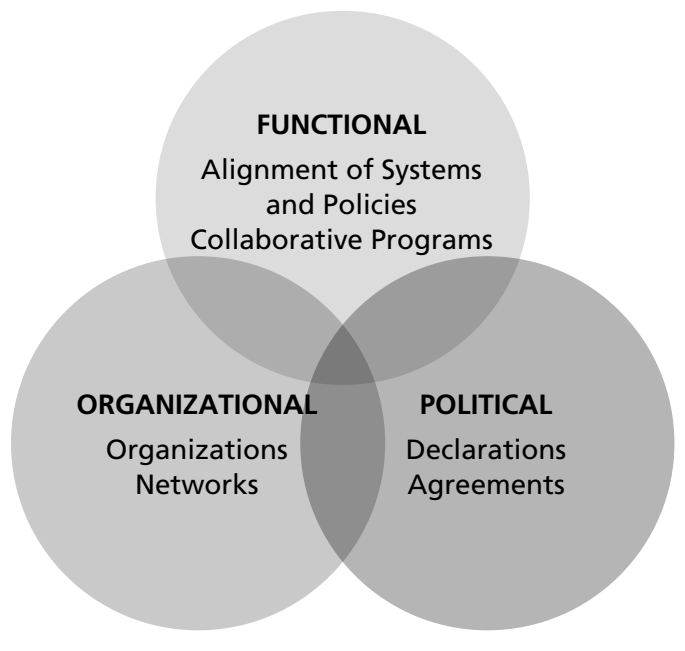

Figure 2

Relationship among 3 Approaches ${ }^{27}$.

The first approach takes a functional perspective of regionalization and focuses on the practical activities of higher education institutions and systems. Functional approach initiatives can be put into two distinct groups. The first group relate to strategies which facilitate closer alignment or in some cases harmonization among national/sub regional higher education systems. The second category includes programs like student mobility schemes, cross-border collaborative education programs, pan-regional universities and centres of excellence. The relationship between these two groups is critical as the systems/policies in group one are needed to facilitate and expedite the programs in group two. For instance, compatibility among quality assurance systems and academic credit systems will help student mobility programs within a region. Generally, it is a more complex and serious undertaking to align national systems within a region than to establish multi-lateral academic activities.

The second approach refers to the organizational architecture that evolves to develop and guide the regionalization initiatives in a more systematic (although some might call bureaucratic) manner. It is labelled organizational approach because frameworks, structures, agencies are

${ }^{27}$ Knight, "A Conceptual Framework for the Regionalization of Higher Education: Application to Asia". 
necessary to help establish and oversee regional level and intra-regional initiatives. A diversity of networks and organizations are emerging which include government and non-government bodies, professional organizations, foundations, and networks. These entities assume a variety of responsibilities - policy-making, funding, research, capacity building, regulation, and advocacy among others. Figure Three presents generic examples of each of the three approaches.

\begin{tabular}{|c|c|}
\hline Approach & Generic Examples \\
\hline Functional & $\begin{array}{l}\text { Alignment of Higher Education Systems } \\
\text { Quality assurance and accreditation } \\
\text { Academic credit system } \\
\text { Degree levels and structures } \\
\text { Recognition of qualifications and titles } \\
\text { Academic calendar - years and semesters } \\
\text { Qualification frameworks } \\
\text { ITC platforms } \\
\text { Research citation index } \\
\text { Inter-library loan systems } \\
\text { Collaborative Academic Programs } \\
\text { Academic mobility schemes- students, professors, scholars } \\
\text { Research networks, clusters, and projects } \\
\text { Cross-border programs- double, joint, twining, branch campus } \\
\text { Regional centres of excellence } \\
\text { Institutional agreements- bilateral and multilateral } \\
\text { OER and ODL } \\
\text { Pan-regional university }\end{array}$ \\
\hline Organizational & $\begin{array}{l}\text { Organizational Architecture } \\
\text { Networks and Organizations } \\
\text { Foundations } \\
\text { Governmental/non-governmental agencies } \\
\text { Frameworks } \\
\text { Levels: pan-regional, regional, sub-regional }\end{array}$ \\
\hline Political & $\begin{array}{l}\text { Political will } \\
\text { Declarations } \\
\text { Agreements/ Conventions/Treaties } \\
\text { Summits/Task Forces/ Dialogues }\end{array}$ \\
\hline
\end{tabular}

Figure 3

FOPA Model - Generic examples ${ }^{28}$.

${ }^{28}$ Knight, "A Conceptual Framework for the Regionalization of Higher Education: Application to Asia". 
The third approach involves the political will and strategies that put higher education initiatives on the agenda of decision making bodies. The political approach helps to launch major programs or funding schemes and to formalize initiatives. Declarations of intent, binding conventions, treaties, agreements, and special meetings like summits or policy dialogues are instruments for generating political support and visibility in order to make regionalization of higher education a priority. This approach can be characterized has having more of a top down, formal and intentional orientation.

\section{Tuning Contributions}

The purpose of this section is to show how Tuning initiatives are directly linked to and contribute to the activities included in the FOPA (see Figure Three). Concrete examples from existing Tuning Projects are used as illustrations.

A clearly stated anticipated outcome for the Latin America Tuning Project is its contribution to creating a Higher Education Area in Latin America. This is realized through curriculum convergence via the development of common reference points for subject profiles and disciplinary frameworks. This, in turn, will lead to more collaboration among academics in curriculum development, joint supervision of research, student mobility and qualifications recognition. Another concrete initiative is the proposed regional system of academic credits based on student workload and learning outcomes, an initiative which started with Tuning's work in Latin America in 2004. These are examples of initiatives to help with the convergence of academic structures at the institutional level and alignment of academic systems at the regional level. ${ }^{29}$

In terms of the organizational architecture necessary for closer regional collaboration in Latin America, Tuning has developed a network of university managers through the National Tuning centres which provide support and build a favourable political context for the universities to work on competency based learning. Furthermore, the Tuning project is partnering with national and regional university associations, quality assurance and accreditation agencies and national government across the region. These groups, along with the universities are key actors to ensure sustainability of the Tuning process and for the regionalization of higher education.

29 Tuning Latin America Project (Tuning Latin America), "Objectives Tuning Latin America," 2011, http://www .tuningal.org/en/tuning-project/objetives. 18 January 2013. 
In Central Asia, where a relatively new Tuning project is in progress, the intention is to develop competency based profiles at the subject level which can serve as the foundation for the eventual development of a Central Asia Qualifications Framework and a regional credit system. ${ }^{30}$ Both the qualification framework and regional academic credit system are key strategies in the FOPA model and fundamental building blocks in for the ultimate goal of creating a Central Asian Higher Education Area.

The African situation is very interesting. Tuning Africa is collaborating with the African Union (AU) to help achieve its Higher Education Harmonization Strategy. One of the key objectives of the AU strategy is to create more student and professional mobility within Africa. To accomplish this goal a regional/sub-regional academic credit systems and a qualification framework are pre-requisites. Furthermore, to enhance the quality of higher education in Africa more attention is being paid to competency-based learning outcomes. Tuning project participants are contributing by identifying a set of common reference points for competencies and professional profiles in five thematic/subject areas. Of special note is the priority to address the application of the Tuning process to distance education in Africa. ${ }^{31}$

The FOPA model focuses on organizational architecture that is necessary to stimulate and sustain regionalization efforts. The Tuning process is creating its own regional networks but more importantly it is working collaboratively with existing regional bodies such as the African Union and sub-regional bodies such as the Central American Council of Universities, both of which are critical actors in the higher education regionalization agenda in their respective regions. In Europe, Tuning is working with and the European Commission to further higher education reform and regionalization within Europe and especially in other countries and regions of the world.

Important to note is that Tuning is also working at the country level, for example China, Japan, USA, Thailand, Russia. It will be interesting to follow the developments at a national level to see if and how they may eventually contribute to the regionalization of higher education.

To date, Tuning initiatives have contributed significantly to the functional aspects of regionalization especially with respect to qualification frameworks, subject/disciplinary profiles and academic credit systems. These issues usually require some level of structure and system alignment within and among countries within a region. These particular reforms in turn facilitate

${ }^{30}$ Wagenaar, "Tuning Educational Structures around the World".

31 Tuning Africa, "Feasibility Study into the Relevance of a Tuning Approach for Higher Education in Africa. Final Report," 2011, http://www.tuningafrica.org/documentos/Final_ report_EDITADO_VERSION_FINAL_30062011.pdf. 21 January 2013. 
program level initiatives such as increased student and scholar mobility, joint cross-border program development, even the development of pan-regional universities. Developing the optimal configuration of organizationsgovernmental/non-governmental, professional, foundations- constitutes the second important approach to regionalization and Tuning has partnered with these groups in addition to the individual higher education institutions, which are the backbone and beneficiaries of any regionalization initiatives. The third approach involves the political will to guide and move the regionalization agenda forward. This is an area where Tuning has some influence by working with regional bodies such as the African Union and the European Commission.

\section{Final words}

New trends and developments such as higher education regionalization bring positive outcomes, but it is important to be mindful of potential negative consequences. Regionalization is a process firmly rooted on respect for differences in local culture and context. But concern lingers that integration can lead to an unintended outcome of standardization and homogenization..$^{32}$ It is crucial that higher education regionalization not become an agent of the zipper effect. The likelihood for this is less when the higher education sector itself is the catalyst and agent for higher education regionalization, but, as pointed out earlier in the paper, there are other policy sectors keen to use higher education as an instrument of regional integration for economic and political purposes. Careful monitoring is critical for all forms of regionalization.

Innovation is a term that is on the lips of leaders and policy makers in all sectors. Higher education is no exception. Innovation is linked with the application of knowledge and insight in new ways. It is essential to keep in mind that any process of alignment, harmonization or convergence of national higher education systems retains the capacity for innovation and change. Introducing another layer of bureaucracy and regulation to higher education need not stifle innovation in the classroom and research centres or, in institutional level governance and national/sub-regional policies. Just as regionalization is adapting to new trends, realities, and opportunities, it in turn needs to accommodate and stimulate new ideas and innovation.

32 Jane Knight, "New Developments and Unintended Consequences: Whither Thou Goest, Internationalization?", in Higher Education on the Move: New Developments in Global Mobility, edited by Rajika Bhandari and Shepherd Laughlin. Global Education Research Reports, 113 -25 (New York: Institute for International Education, 2009). 
This paper proposed and discussed the FOPA model for analysing the complex and evolving phenomenon of higher education regionalization and demonstrated how Tuning initiatives relate closely to the model and are direct contributors to the regionalization process. There is no one way or right way to go about higher education regionalization. Each region, however defined, will develop its own path which acknowledges and respects the commonalities and differences among higher education institutions and systems. The academic, social, cultural, human and political benefits of higher education regionalization are many and diverse, but there are pitfalls along the way as well. The roadmap is not fully developed. Regionalization is an evolutionary process which builds on existing realities, current initiatives such as Tuning, and future endeavors which involve functional, organizational and political strategies that complement one other.

\section{Bibliography}

African Union. "Harmonization of Higher Education Programmes in Africa: A Strategy for the African Union: Summary Report." Addis Ababa: Meeting of the Bureau of the Conference of Ministers of Education of the African Union (COMEDAF II+), African Union, 2007.

Alarcon, Francisco. "Vinculando Tuning a las Políticas Nacionales, Subregionales y Regionales: La Experiencia de América Central." Presentation of 4th Tuning Project Meeting in Brussels. Tuning America Latina, 2012. http://www.tuningal. org/es/publicaciones/cat_view/44-presentaciones-reunion-bruselas-19-22nov-2012. 19 January 2013.

Aphijanyathan, R. "A Research Report on East Asian Internationalization of Higher Education: A Key to Regional Integration.” Program Report 24. Bangkok: Regional Centre for Higher Education and Development, South East Ministers of Education Organization, 2010.

Beneitone, Pablo, Cesar Esquetini, Julia González, Maida Marty Maleta, Gabriela Siufi, Robert Wagenaar, Cesar Esquetini, et al. "Reflections on and Outlook on Higher Education in Latin America - Final Report Tuning Latin America Project 2004-2007." University of Deusto and University of Groningen, 2007. http://www.unideusto.org/tuningeu/images/stories/Publications/Tuning_A_ Latina_INGL_PR2.pdf. 18 January 2013.

González, Julia, and Robert Wagenaar. "Universities' Contribution to the Bologna Process. An Introduction.” University of Deusto, 2008. http://www.unideusto. org/tuningeu/images/stories/Publications/ENGLISH_BROCHURE_FOR_ WEBSITE.pdf. 19 January 2013.

Gorga, Adriana. "Where Are We with the Harmonization of European Higher Education? The Case of Central and East European Countries." European Education 39, no. 4 (2008): 58-68 
Hettne, Björn. "Beyond the New Regionalism." New Political Economy 10, no. 4 (2005): 543-71.

Hoosen, Sarah, Neil Butcher, and Beatrice Khamati Njenga. "Harmonization of Higher Education Programmes: A Strategy for the African Union." African Integration Review 3, no. 1 (2009): 1-36.

Knight, Jane. "A Conceptual Framework for the Regionalization of Higher Education: Application to Asia." In Higher Education Regionalization in Asia Pacific. Implications for Governance, Citizenship and University Transformation, edited by John N. Hawkins, Ka Ho Mok and Deane E. Neubauer. London: Palgrave Macmillan, 2012.

- Higher Education in Turmoil: The Changing World of Internationalization. Global Perspectives on Higher Education, V. 13. Rotterdam: Sense Publishers, 2008.

— . "New Developments and Unintended Consequences: Whither Thou Goest, Internationalization?". In Higher Education on the Move: New Developments in Global Mobility, edited by Rajika Bhandari and Shepherd Laughlin. Global Education Research Reports, 113 -25. New York: Institute for International Education, 2009.

- "Towards African Higher Education Regionalization and Harmonization: Functional, Organizational and Political Approaches." In The Development of Higher Education in Africa: Prospects and Challenges, edited by Alexander W. Wiseman and C. Wolhuter. International Perspectives on Education and Society Series. UK: Emerald Publishing, 2013.

Kuroda, Kazuo, and D. Passarelli, eds. Higher Education and Asian Regional Integration Symposium Report. Tokyo: Global Institute for Asian Regional Integration, Waseda University, 2009.

Njenga, Beatrice. "Tuning Approach for Harmonisation of Higher Education in Africa." Presentation of 4th Tuning Project Meeting in Brussels. Tuning Latin America, 2012. http://www.tuningal.org/es/publicaciones/cat_view/44presentaciones-reunion-bruselas-19-22-nov-2012. 19 January 2012.

Robertson, Susan. "Europe/Asia Regionalism, Higher Education and the Productions of World Order “. Policy Futures in Education 6, no. 6 (2008): 718-29.

Robledo, R., and A. Caillon. "Regional Processes in Higher Education. The University Course Accreditation Mechanisms in the MERCOSUR and Regional Recognition of Diplomas and the Quality of Training." Journal of Higher Education and Society 14, no. 1 (2009): 73-98.

Tauch, Christian. "The Bologna Process: State of Implementation and External Dimension." In Opening up to the Wider World: The External Dimension of the Bologna Process, edited by F. Muche. ACA Papers on International Cooperation in Education, 23-29. Bonn: Lemmens, 2005.

Terada, Takashi. “Constructing an 'East Asian' Concept and Growing Regional Identity: From EAEC to ASEAN+3." The Pacific Review 16, no. 22 (2003): 51-277.

Tuning Africa Project (Tuning Africa). "Feasibility Study into the Relevance of a Tuning Approach for Higher Education in Africa. Final Report." 2011. 
http://www.tuningafrica.org/documentos/Final_report_EDITADO_VERSION_ FINAL_30062011.pdf. 21 January 2013.

Tuning Latin America Project (Tuning Latin America). “Objectives Tuning Latin America.” 2011. http://www.tuningal.org/en/tuning-project/objetives. 18 January 2013.

Vayrynen, Raimo. "Regionalism: Old and New." International Studies Review 5, no. 1 (2003): 25-51.

Verger, Antoni, and Javier P. Hermo. "The Governance of Higher Education Regionalisation: Comparative Analysis of the Bologna Process and MERCOSUR-Educativo." Globalisation, Societies and Education 8, no. 1 (2010): 105-20

Wagenaar, Robert. "Tuning Educational Structures around the World. An Overview of the Developments in Different Regions." Presentation of 4th Tuning Project Meeting in Brussels. Tuning Latin America, 2012. http:/www.tuningal.org/es/ publicaciones/cat_view/44-presentaciones-reunion-bruselas-19-22-nov-2012. 19 January 2013.

Woldetensai, Yohannes. Regional Harmonization of Higher Education for Africa: Background Document. Accra: Association of African Universities, 2009.

Yavaprabhas, Supachai. "Experiences of Asian Higher Education Frameworks and Their Implication for the Future." GIARI Working Paper 2008-E.19. Tokyo: Waseda University, 2009.

_. "Regional Harmonization of Higher Education in Asean." Paper presented at the 2010 Global Higher Education Forum, Penang (Malaysia), 2010. 